\author{
B. Helliot $\cdot$ R. Swennen $\cdot$ Y. Poumay $\cdot$ E. Frison \\ P. Lepoivre $\cdot$ B. Panis
}

\title{
Ultrastructural changes associated with cryopreservation of banana (Musa spp.) highly proliferating meristems
}

Received: 26 March 2002 / Revised: 15 July 2002 / Accepted: 29 August 2002 / Published online: 19 November 2002

(C) Springer-Verlag 2002

\begin{abstract}
Cryopreservation has been shown to improve the frequency of virus elimination - specifically cucumber mosaic virus and banana streak virus - from banana (Musa spp.) plants. To understand the mode of action of cryopreservation for the eradication of viral particles, we examined the ultrastructure of meristem tips at each step of the cryopreservation process. Excised meristematic clumps produced from infected banana plants belonging to cv. Williams (AAA, Cavendish subgroup) were cryopreserved through vitrification using the PVS-2 solution. We demonstrated that the cryopreservation method used only allowed survival of small areas of cells in the meristematic dome and at the base of the primordia. Cellular and subcellular changes occurring during the cryopreservation process are discussed.
\end{abstract}

Keywords Banana streak virus - Cucumber mosaic virus - Cryopreservation $\cdot$ Electron microscopy $\cdot$ Musa

\section{Introduction}

For many crops, cryopreservation is currently being applied to overcome the limitations encountered by traditional germplasm conservation strategies in field, seed and in vitro culture collections. Conservation at ultralow temperatures - usually at $-196^{\circ} \mathrm{C}$, which is the tem-

Communicated by P. Debergh

B. Helliot · P. Lepoivre ( $)$

Plant Pathology Unit, Gembloux Agricultural University,

5030 Gembloux, Belgium

e-mail: lepoivre.p@fsagx.ac.be

R. Swennen $\cdot$ B. Panis

Laboratory of Tropical Crop Improvement, K.U. Leuven,

3001 Leuven, Belgium

Y. Poumay

Department of Histology-Embryology, FUNDP, 5000 Namur, Belgium

E. Frison

INIBAP/IPGRI, 34397 Montpellier, France perature of liquid nitrogen - enables long-term and contamination-free storage of plant genetic resources. In 1997, Brison and co-workers demonstrated for the first time that cryopreservation is not only applicable for germplasm conservation but also for virus eradication. As such, cryopreservation resulted in $50 \%$ virus-free in vitro plants from plum shoots infected with plum pox virus.

Bananas, which belong to the Musa genus, are found in about 120 countries, mainly tropical and subtropical, on five continents. This important crop provides staple food to millions of people around the world (Frison and Sharrock 1999). However, banana plants are threatened by various biotic agents such as bacteria, fungi and viruses, all leading to considerable yield losses (Jones 2000). Helliot et al. (2002) reported the successful application of cryopreservation for cucumber mosaic virus and banana streak virus elimination from banana plants using a cryopreservation protocol developed by Panis et al. (1996, 2000a). The cryopreservation of embryogenic banana cell suspensions also proved to be of great value for the stable, long-term storage of this transformation competent material (Panis et al. 1990, 2000b). The possibility of applying a short (few hours) cryotherapy instead of a long (few weeks to several years) traditional treatment would be highly attractive with respect to virus elimination. However, to date, little is known about the mode of action of cryopreservation. Cryopreservation through the application of vitrification solutions, first reported in plant cells by Uragami et al. (1989) and Langis et al. (1989), is becoming increasingly the method of choice for the long-term conservation of plant tissues. Ultrastructural studies related to plant cryopreservation are rather scarce. Moreover, the effect of vitrification solutions and subsequent freezing on plant cell ultrastructure has only been reported twice (Tannoury and Vintéjoux 1997; Wang et al. 1998).

Light microscopic observations performed on frozen banana highly proliferating meristems (Helliot et al. 2002) showed that during cryopreservation highly vacuolated cells are destroyed with the result that only a few 
layers of meristematic cells localised in the tunica and in leaf primordia remained alive following cryopreservation. These data combined with the putative localisation of viral particles in meristems (Faccioli and Marani 1998; our unpublished results) could explain the mode of action of cryopreservation as a virus eradication therapy.

In the framework of an INIBAP program entitled "Development of in vitro culture techniques for the virus diseases elimination from Musa" (Helliot et al. 2001), we have studied highly proliferating meristem cultures of banana at each step of the cryopreservation process. Using electron microscopy, we have attempted to understand the effect of cryopreservation on the highly proliferating meristem structure and, subsequently, to explain the resulting virus eradication rates.

\section{Materials and methods}

Plant material

The banana cultivar Williams BSJ (ITC. 0570), which was stored in vitro at the INIBAP Transit Center (ITC, Leuven, Belgium), was chosen as a model since it responds well to the different tissue culture techniques and is moreover an important dessert banana (Daniells et al. 2001).

Production of highly proliferating meristem clumps

In order to produce highly proliferating meristem cultures consisting of white clumps of numerous shoot meristematic structures, we plated in vitro shoots on MS semi-solid medium (Murashige and Skoog 1962) supplemented with $100 \mu M \mathrm{~N}^{6}$-benzyladenine (BA), $1 \mu M$ indole-3-butyric acid and 3\% sucrose ( $\mathrm{p} 4$ medium). Every 1 to 2 months, the material was subcultured, and only small clumps of proliferating meristems were selected and transferred to fresh medium.

Cryopreservation protocol

Preculture

White meristematic clumps ( $4 \mathrm{~mm}$ in diameter) containing at least four apical domes were transferred onto the preculture medium. This medium is identical to $\mathrm{p} 4$ medium with the exception of a lowered BA concentration $(10 \mu M)$ and a higher sucrose concentration $(0.4 M)$. These cultures were maintained for 2 weeks.

\section{Loading}

Sucrose-precultured meristematic clumps (1.5-3 $\mathrm{mm}$ in diameter) were isolated and kept for $20 \mathrm{~min}$ in a filter-sterilised loading solution ( $2 M$ glycerol and $0.4 M$ sucrose dissolved in MS medium, $\mathrm{pH} 5.8)$ at room temperature.

\section{Treatment with vitrification solution (dehydration) and freezing}

The loading solution was replaced by ice-cooled and filter-sterilised PVS-2 solution (Sakai et al. 1990) containing 30\% (3.26 M) glycerol, $15 \%(2.42 M)$ ethylene glycol, $15 \%(1.9 M)$ dimethylsulfoxide and $0.4 M$ sucrose dissolved in MS medium ( $\mathrm{pH}$ 5.8). Meristematic clumps were immersed in the PVS-2 solution for $120 \mathrm{~min}$ at $0^{\circ} \mathrm{C}$, transferred to $2-\mathrm{ml}$ cryotubes and immersed into liquid nitrogen for a minimum of $1 \mathrm{~h}$.

\section{Thawing and deloading}

Tubes containing meristematic clumps were rapidly thawed in a warm water bath $\left(40^{\circ} \mathrm{C}\right)$ for $80 \mathrm{~s}$. The PVS-2 solution was replaced by the filter-sterilised deloading solution (1.2 $\mathrm{M}$ sucrose dissolved in MS medium, $\mathrm{pH}$ 5.8) for $15 \mathrm{~min}$ at room temperature.

\section{Recovery}

Control meristematic clumps were loaded, dehydrated and deloaded but not frozen, while frozen meristems were taken from the deloading solution and placed in 9-cm plastic petri dishes onto two sterile filter papers on top of semi-solid hormone-free MS medium containing $0.3 M$ sucrose. After 2 days, the meristem clumps were transferred onto regeneration medium. The first week of culture always took place in the dark.

Electron microscopic observations

The following samples were prepared for microscopy:

1. Highly proliferating meristems;

2. Highly proliferating meristems cultured for 2 weeks on MS medium supplemented with $0.4 \mathrm{M}$ sucrose (preculture);

3. Precultured meristems loaded with $2 M$ glycerol and $0.4 M$ sucrose, followed by a 2-h dehydration with PVS-2 (Sakai et al. 1990);

4. Same as (3), and subsequently subjected to liquid nitrogen for $1 \mathrm{~h}$;

5. Cryopreserved meristem cultures after a 1-week recovery on MS medium.

Chemical fixation of highly proliferating meristem clumps or an excised meristem was performed using a $2.5 \%$ glutaraldehyde [in $0.1 M$ phosphate buffer ( $\mathrm{pH} 7.2)]$ solution. The tissue samples were first subjected to vacuum (three times $5 \mathrm{~min}$ ) in a desiccator, then kept overnight at $4^{\circ} \mathrm{C}$ and post-fixed with a $1 \%$ osmic acid [in $0.1 M$ phosphate buffer ( $\mathrm{pH}$ 7.2)] solution. The samples were then dehydrated using an incremental ethanol series $(50 \%, 70 \%$, $85 \%$ and $95 \%$ ) in a $0.85 \%$ saline solution ( $1 \mathrm{~h}$ on ice for each ethanol dilution) and stored in $100 \%$ ethanol (overnight at $4^{\circ} \mathrm{C}$ ).

After dehydration, samples were embedded in a mould filled with Epon 812 resin and kept in an oven for $3-4$ days at $60^{\circ} \mathrm{C}$ for polymerisation. Thin sections were cut on a Pyramitome 11800 (LKB Bromma) with glass knives and stained with toluidine blue. These sections were observed with a light microscope (Olympus AX 70).

For electron microscopy, the thin sections were picked up on Formar $(0.2 \%$ in chloroform)-coated 300-mesh grids (Maxtaform $\mathrm{HR} 25, \mathrm{Cu} / \mathrm{Rh}$ ), post-stained with uranyl acetate (2\% in $50 \%$ alcohol) for 20 min followed by lead citrate (Reynolds 1963) for $2 \mathrm{~min}$. A Tecnaï 10 (Philips) transmission electron microscope operating at $60 \mathrm{kV}$ was used equipped with a SIS Megaview II camera.

\section{Results and discussion}

There is a need to understand the mode of action of cryopreservation in order to improve the protocol for germplasm conservation and virus eradication in Musa. Therefore, ultra-structural observations on cryopreserved highly proliferating meristems were performed and compared with control meristems.

A characteristic of the control meristematic cells was their small size (approx. 20-30 $\mu \mathrm{m}$ in diameter) and a high nucleo-cytoplasm ratio typical of actively dividing cells (Fig. 1a). Previous light microscopic observations revealed that this nucleo-cytoplasm proportion decreases with increasing distance from the meristematic dome 

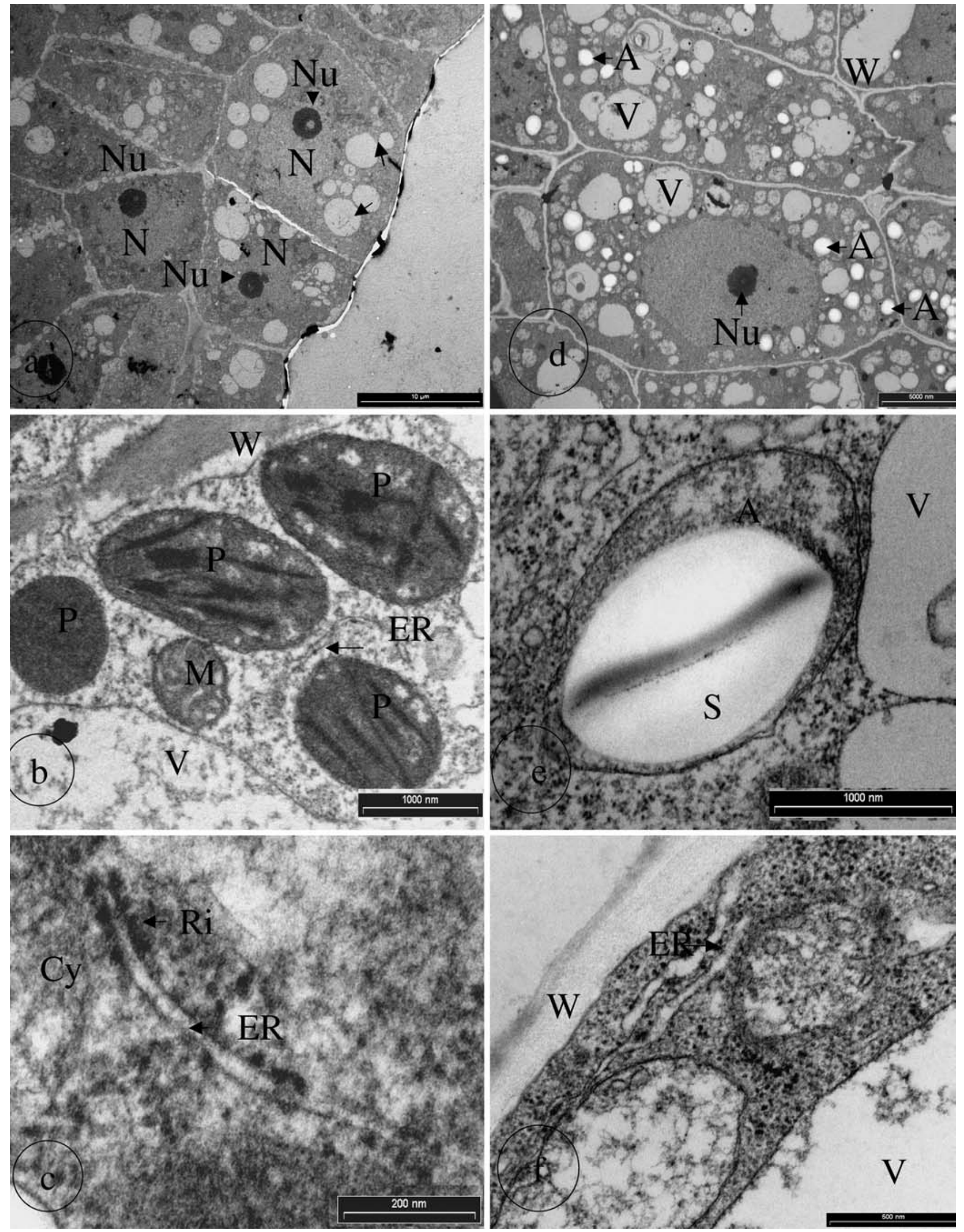
(Helliot et al. 2002). The electron microscope revealed the presence of a prominent nucleolus in the rounded nucleus and small patches of heterochromatin on the nuclear periphery. The cytoplasm contained many small vacuoles. The presence of a large number of cell organelles Golgi apparatus, proplastids and mitochondria (Fig. 1b) and an endoplasmic reticulum associated with ribosomes (Fig. 1c) - is characteristic of a highly active cell metabolism.

The preculture of proliferating meristems was performed on a medium supplemented with an elevated concentration of sucrose $(0.4 \mathrm{M}$ instead of $0.1 \mathrm{M}$ in the regular MS culture medium) to induce a tolerance to the dehydration stress that is caused by exposure to a concentrated PVS-2 solution. This 'hardening' treatment, which leads to the mitigation of the subsequent injurious effects of the PVS-2 solution, is necessary for successful cryopreservation.

Sucrose preculture of proliferating meristems resulted in numerous ultrastructural changes; for example, the fragmentation of vacuoles into smaller ones (Fig. 1d), the differentiation of proplastids into amyloplasts containing starch (Fig. 1e) and the swelling of organelles like the endoplasmic reticulum (Fig. 1f) as previously reported by Takashi et al. (1997). Alterations in the biomembranes were also observed, such as the presence of multi-membranous structures and the undulations of the plasma membrane caused by partial plasmolysis (Fig. 1d).

Vandenbussche et al. (1999) measured the sucrose uptake in in vitro shoots of sugar beet after a 1-week preculture on a medium enriched with $0.3 M$ sucrose and demonstrated the uptake of free sugars by the apical dome. Panis (1995) emphasised the role of sucrose preculture in the slow reduction of moisture content to lower the amount of freezable water. The osmotic effect of the disaccharide is probably strengthened by its dissociation into monosaccharides (Uragami et al. 1990). Sugars can also maintain the liquid crystalline state of the membrane bilayers and stabilise proteins under frozen conditions (Kendall et al. 1993). Disaccharides such as sucrose seem to be especially very effective membrane protectors (Crowe et al. 1984). The protective effect of soluble sugars on membrane stability during drought and freeze-induced desiccation relies on their ability to form hydrogen bonds with the polar headgroups of membrane phospholipids and thus to replace water molecules bound to phospholipids in the hydrated state (Crowe et al. 1984). An indirect effect of

4 Fig. 1a-e Electron microscopy of meristematic cells from highly proliferating meristems. a-c Control meristematic cells: a cells located at the periphery of the meristematic dome, $\mathbf{b}$ mitochondria and proplastids, $\mathbf{c}$ rough endoplasmic reticulum. d-f Meristematic cell after a 2-week preculture on a MS medium supplemented with $0.4 M$ sucrose: d fragmentation of vacuoles into smaller ones, e amyloplasts containing starch grain, $\mathbf{f}$ swollen endoplasmic reticulum. A Amyloplast, $C y$ cytosol, ER endoplasmic reticulum, $M$ mitochondrion, $N$ nucleus, $N u$ nucleolus, $P$ proplastid, $R i$ ribosomes, $S$ starch grain, $V$ vacuole, $W$ cell wall a sucrose treatment, which exercises a mild osmotic stress upon the tissue, could consist of the accumulation of water stress-protective compounds like proline (Delvallée et al. 1989). Some plant genes are induced by high sugar concentrations (Koch 1996). A change in the protein pattern through cryoprotection using a sugar treatment was described for somatic embryos of Daucus carota (Thierry et al. 1999).

Cryopreservation is only successful if intracellular ice crystal formation, which is mainly associated with physical damage to the membranes, is avoided. The only way to prevent ice crystal formation at ultra-low temperatures without an extreme reduction in cellular water is through vitrification - the non-crystalline solidification of water. Two requirements must be met for a solution to vitrify: (1) the solution needs to be concentrated with appropriate solutes, and (2) the cooling rates need to be rapid (Sakai 2000).

In the present study, cell solute concentration was achieved through a 2-h treatment with the PVS-2 solution (Sakai et al. 1990) at $0^{\circ} \mathrm{C}$. This mixture contains high concentrations of penetrating cryoprotectants (dimethylsulfoxide and glycerol) as well as osmotically active compounds (ethylene glycol and sucrose). The effects of PVS-2 varied, producing minor (Fig. 2a), mild (Fig. 2b) or severe (Fig. 2c) plasmolysis in cells of the corpus after a 2-h cryoprotection. Severely plasmolysed cells probably lost all contact with neighbouring cells since intracellular connections (through the plasmodesmata) were broken. In most of the PVS-2-treated cells, the nuclear content also was less electron-dense compared to the nuclear content of untreated cells (Fig. 2d).

After cryopreservation, severe abnormalities occurred in many cells (Fig. 3a). Localisation of the damaged cells indicated that freezing injuries were linked with increased vacuolisation (Helliot et al. 2002). In fact, freezing injury has been reported to be primarily the result of intracellular water crystallisation, which occurs either during the cooling and/or the thawing steps. The latter is referred to as devitrification, i.e. crystallisation of a vitrified solution during thawing. The more vacuolised the plant cells are, the more water that needs to be withdrawn from the cells to prevent lethal ice crystallisation. The key to successful cryopreservation thus lies more in the induction of a tolerance towards dehydration instead of a tolerance to the freezing process itself.

Osmiophilic globules close to the cell wall were observed (Fig. 3b). Tannoury and Vintejoux (1997) assumed that those globules would be involved in the cellular traffic of compounds generated by the stresses of the dehydration, cooling or warming step.

Using freeze electron microscopy Fujikawa (1994) showed that growing intracellular ice crystals cause mechanical forces which disorganise the lipid bilayers. In our study, expansions in the nucleus cisternal spaces were observed (Fig. 3c); these resulted in abnormalities in the nuclear envelope and led in certain cells to the rupturing of the nuclear envelope (Fig. 3d). According to 

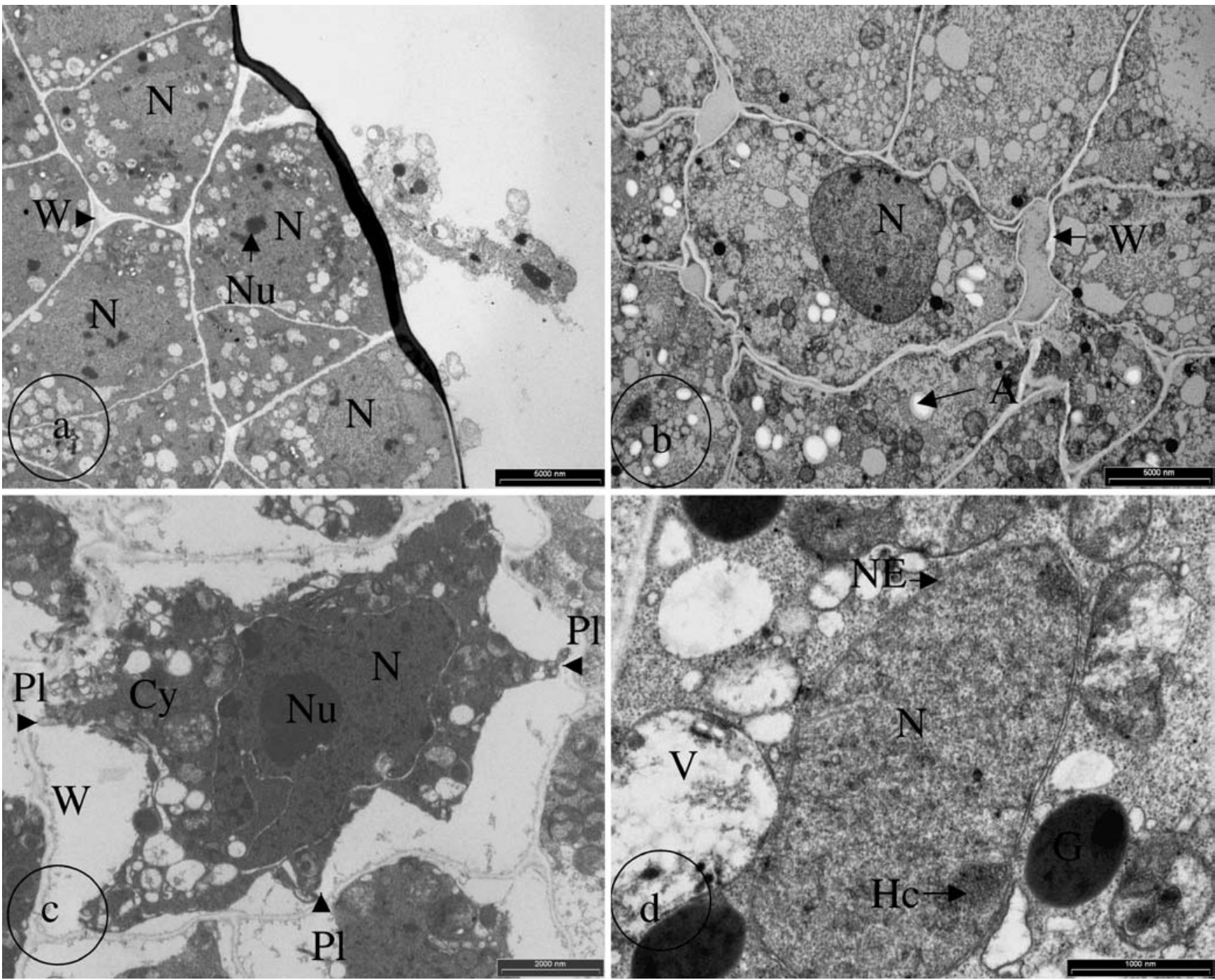

Fig. 2a-d Electron microscopy of meristems excised from highly proliferating meristems after a 2-week preculture on MS medium supplemented with $0.4 M$ sucrose +2 h of cryoprotection in PVS2 solution at $0^{\circ} \mathrm{C}$. a Minor effect, b mild plasmolysis, c severe plasmolysis, d less dense nucleus. A Amyloplast, $C y$ cytoplasm, $G$ electron-dense globule, $H c$ heterochromatin, $N$ nucleus, $N E$ nuclear envelope, $\mathrm{Nu}$ nucleolus, $\mathrm{Pl}$ plasmodesmata connection, $\mathrm{W}$ cell wall

Wang et al. (1998), these cisternal spaces are induced by the rupture of several nearby nucleus pore complexes, as previously observed in PVS-2-dehydrated rice embryogenic cell suspension cells. Moreover, nucleoli adopted a lacunar aspect with the presence of many vacuoles (Fig. 3e), which could be either the result of a cessation in nucleolar activity (Tannoury and Vintejoux 1997) or the formation of small ice crystals.

After 1 week of post-thaw recovery meristematic clumps were again observed (Fig. 4). Small areas of surviving cells were identified in primordial leaf tissues and in the tunica of the meristematic dome (Fig. 4a). The recovering cells were similar in appearance to control cells

(Fig. 4b). Surviving cells showed the presence of numerous organelles (Fig. 4b, c), suggesting an intense metabolic activity. These small areas of surviving cells, previously shown by Helliot (1998) on cryopreserved meristems of plum, keep their capacity for active cell division and structural organisation leading to the regeneration into whole plants (Haskins and Kartha 1980). After freezing/thawing, electron-dense granules accumulated in the vacuole, which may represent an accumulation of toxic polyphenolic compounds (Fig. 4c-e). Banana tissues are known to produce massive amounts of polyphenols, which oxidise rapidly as a reaction to different stress conditions. (Gupta 1986) Damaged cells lacked most of the membranous structures and were characterised by the disintegration of their cellular contents (Fig. 4f) and by the dispersion of the polyphenolic compounds. Only starch grains remained intact.

In our previous paper it was proven that the cryopreservation of meristem clumps infected with cucumber mosaic virus (CMV) and banana streak virus resulted in $30 \%$ and $90 \%$ disease-free plants, respectively. Our ultrastructural study of banana highly proliferating meri- 

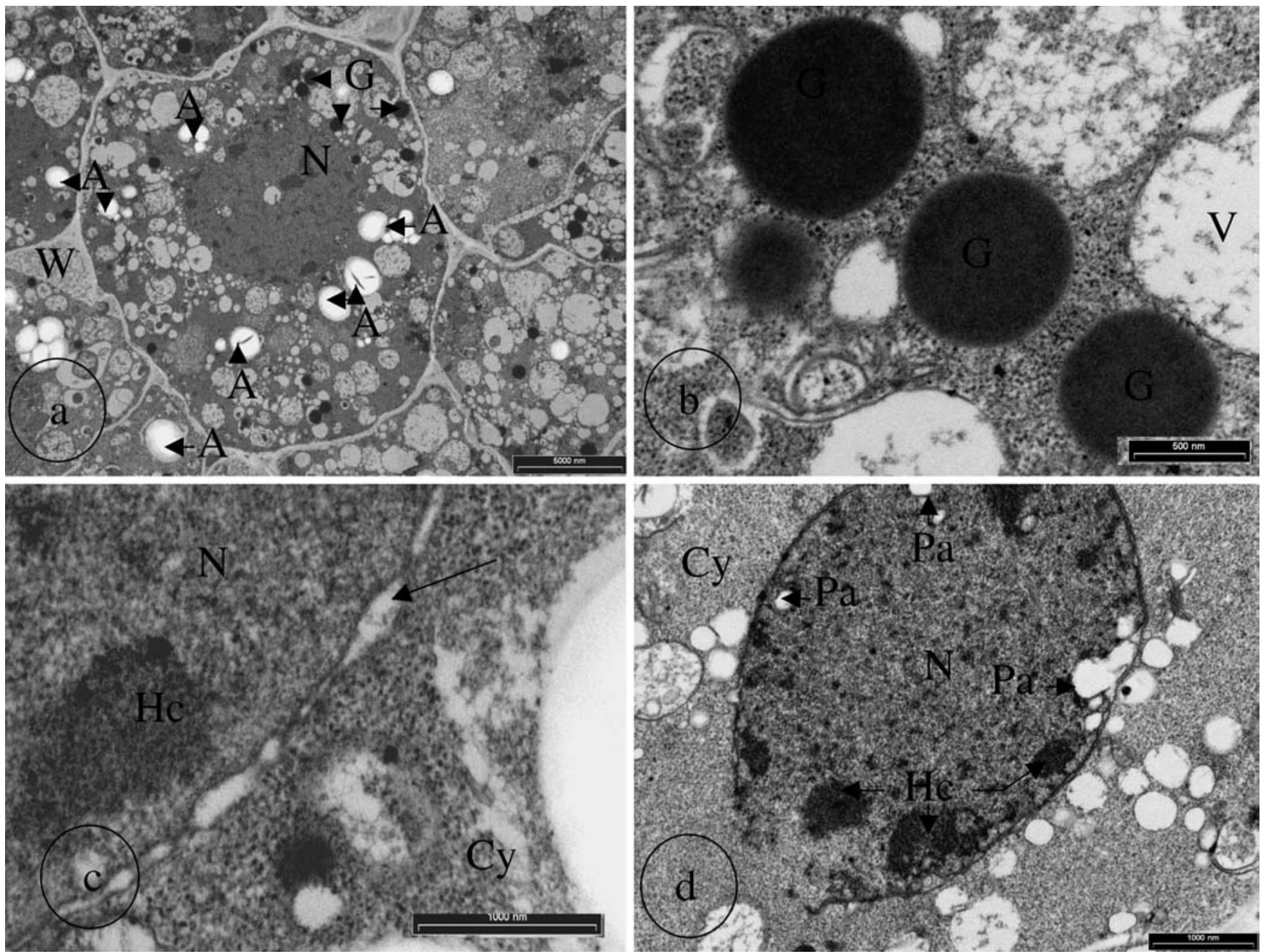

Fig. 3a-e Electron microscopy of meristems excised from highly proliferating meristems after a 2-week preculture on a MS medium supplemented with $0.4 \mathrm{M}$ sucrose $+2 \mathrm{~h}$ of cryoprotection in PVS-2 solution, cooled in LN and held there for $1 \mathrm{~h}$ and subsequently warmed. a Representative cells, b electron-dense globules, $\mathbf{c}$ irregular extension of the nuclear envelope, $\mathbf{d}$ disruption of the nuclear envelope, $\mathbf{e}$ fewer electron-dense patches and irregular dispersal of heterochromatin in the nucleus and lacunar nucleolus. $A$ Amyloplast, $N$ nucleus, $N E$ nuclear envelope, $N u$ nucleolus, $\mathrm{G}$ electron-dense globule, $\mathrm{Hc}$ heterochromatin, $\mathrm{Pa}$ less electrondense patches, $V$ vacuole

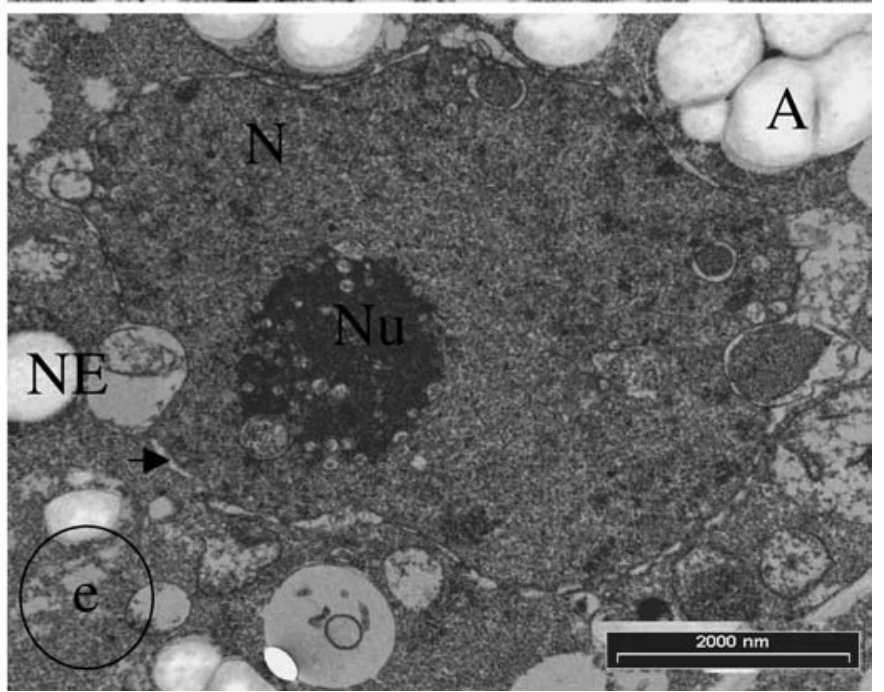

stems at different stages of the cryopreservation process was carried out to understand the mode of action of cryotherapy at the sub-cellular level. It is generally accepted that virus particles are unevenly distributed throughout the meristem. This was recently confirmed through the immunolocalisation of CMV in banana mer- istem (our unpublished data). The application of the "classical" meristem-tip culture protocol to eradicate viral particles was initially based on the concept of meristem "immunity" towards viruses (Morel 1948). In this respect, different researchers have shown that the probability of obtaining virus-free plants is inversely related 

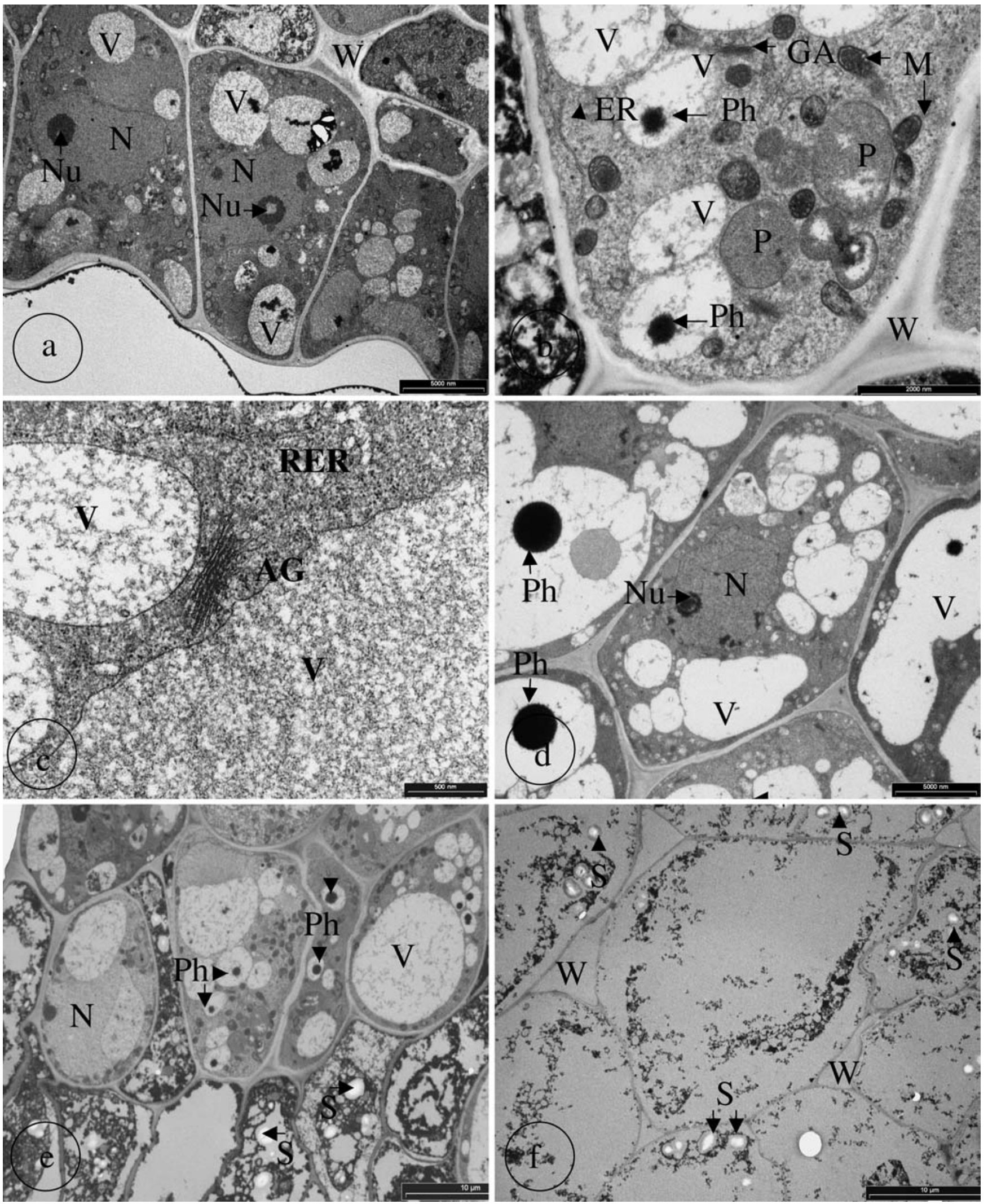

Fig. 4a-f Light microscopy $(L M)$ and electron microscopy $(E M)$ of meristem excised from highly proliferating meristem after a 2week preculture on a MS medium supplemented with $0.4 M$ sucrose $+2 \mathrm{~h}$ of cryoprotection in PVS-2 solution, cooled in LN and held there for $1 \mathrm{~h}$, subsequently warmed and regenerated for 1 week on MS medium. a Small areas of surviving cells on the top

of the meristem tip, b surviving cells, c numerous organelles, d polyphenolic compounds in the vacuoles, e border region between dead and living areas, f disintegrated cells with starch grains. $G A$ Golgi apparatus, $M$ mitochondrion, $N$ nucleus, $N u$ nucleolus, $P$ proplastid, $P h$ polyphenolic compounds, $R E R$ rough endoplasmic reticulum, $S$ starch, $V$ vacuole, $W$ cell wall 
to the size of the excised meristem (Faccioli and Marani 1998). The reason for this uneven distribution of virus particles could be that the meristematic tissue grows faster then the virus particles can migrate into the apical dome. Evidence exists, however, that CMV particles are still present in the apical meristem (Walkey 1978) and that, despite this presence, virus-free plants can be regenerated through meristem culture. Matthews (1991) suggested that in dividing cells, plant mRNAs that are present at high concentrations in active cells, might compete effectively with viral RNAs for the translation apparatus.

Our observations revealed that the majority of the meristematic cells were injured either during the freezing/thawing step or during the osmotic dehydration step with PVS-2. Thus, only very small areas located in the periphery of the meristematic dome survived the cryopreservation process, thereby increasing the probability of regenerating plants from virus-free cells. Now that cryopreservation protocols are developed for a continuously increasing number of plant species, cryotherapy could be considered as an efficient alternative to the classical plant virus eradication techniques.

Acknowledgements We thank A. Locicero (FUSAGx, Belgium), K. Reyneirs (K.U. Leuven, Belgium) and C. Devignon (FUNDP, Belgium) for their technical help in virus detection, in cryopreservation and in the preparation of the ultra-thin sections, respectively. The current study was performed in the framework of an INIBAP (International Network for the Improvement of Banana and Plantain) project entitled "Development of in vitro culture techniques for the virus diseases elimination from Musa" and was largely supported with funding provided by the Directorate General for International Cooperation (DGIC, Belgium). This work is part of the global PROMUSA program.

\section{References}

Brison M, de Boucaud MT, Pierronnet A, Dosba F (1997) Effect of cryopreservation on the sanitary state of a cv. Prunus rootstock experimentally contaminated with Plum Pox Potyvirus. Plant Sci 123:189-196

Crowe HH, Crowe LM, Carpenter JF, Aurell-Winstrom C (1984) Stabilisation of dry phospholipid bilayers and proteins by sugars. Plant Cell Rep 12:89-94

Daniells J, Jenny C, Karamura D, Tomekpe K (2001) Williams, cultivated varieties AAA. In: Arnaud E, Sharrock S (eds) Musalogue: a catalogue of Musa germplasm-diversity in the genus Musa. INIBAP, Montpellier, France, p 67

Delvallée I, Guillaud J, Beckert M, Dumas C (1989) Cryopreservation of immature maize embryos after freeze-hardening in the ear and in vitro. Plant Sci 60:129-136

Faccioli G, Marani F (1998) Virus elimination by meristem tip culture and tip micrografting. In: Hadidi A, Khetarpal RF, Koganezawa H (eds) Plant virus diseases control. APS Press, The American Phytopathological Society, St. Paul, pp 346380

Frison EA, Sharrock S (1999) The economic, social and nutritional importance of banana in the world. In: Picq C, Fouré E, Frison EA (eds) Banana and food security. INIBAP, Montpellier, France, pp 21-35

Fujikawa S (1994) Ultrastructural studies of intracellular freezing: diversity of alterations in the plasma membrane upon freezing, thawing and recooling. Cryo-Letters 15:223-234
Gupta PP (1986) Eradication of mosaic disease and rapid clonal multiplication of bananas and plantains through meristem tip culture. Plant Cell Tissue Organ Cult 6:33-39

Haskins RH, Kartha KK (1980) Freeze preservation of pea meristems: cell survival. Can J Bot 58:833-840

Helliot B (1998) Croissance et Stabilité génétique des Vitroplants de Prunier Ferlenain Plumina (R) après cryoconservation des méristèmes. $\mathrm{PhD}$ thesis, Université de Bordeaux 1, France

Helliot B, Panis B, Locicero A, Reyniers K, Muylle H, Vandewalle M, Michel C, Swennen R, Lepoivre P (2001) Development of in vitro techniques for the elimination of viral diseases from Musa spp. In: Proc 4th Int Symp In Vitro Cult Hortic Breed. Acta Hortic 560:535-538

Helliot B, Panis B, Swennen R, Lepoivre P, Frison E (2002) Cryopreservation for the elimination of cucumber mosaic or banana streak viruses from banana (Musa spp.). Plant Cell Rep 20: $1117-1122$

Jones DR (2000) Diseases of banana, abaca and ensete. CABI, UK

Kendall EJ, Kartha KK, Qureshi JA, Chermak P (1993) Cryopreservation of immature spring wheat zygotic embryos using abscisic acid pretreatment. Plant Cell Rep 12:89-94

Koch KE (1996) Carbohydrate-modulated gene expression in plants. Annu Rev Plant Physiol Plant Mol Biol 47:509-540

Langis R, Schnabel B, Earle ED, Steponkus PL (1989) Cryopreservation of Brassica campestris L. cell suspensions by vitrification. Cryo-Letters 10:421-428

Matthews REF (1991) Transmission, movement and host range. In: Matthews REF (ed) Plant virology, 3rd edn. Academic Press/Harcourt Brace Jovanovich, San Diego, pp 358-371

Morel G (1948) Recherches sur la culture associée de parasites obligatoires et de tissus végétaux. Ann Epiphyt 1:123-234

Murashige T, Skoog F (1962) A revised medium for rapid growth and bioassays with tobacco tissues cultures. Physiol Plant 15:473-497

Panis B (1995) Cryopreservation of banana (Musa sp.) germplasm. Dissertationes de Agricultura no. 272, Katholieke Universiteit Leuven, Belgium

Panis B, Withers LA, De Langhe E (1990) Cryopreservation of Musa suspension cultures and subsequent regeneration of plants. Cryo-Letters 11:337-350

Panis B, Totte N, Van Nimmen K, Withers LA, Swennen R (1996) Cryopreservation of banana (Musa spp.) meristems cultures after preculture on sucrose. Plant Sci 21:95-106

Panis B, Schoofs H, Thinh NT, Swennen R (2000a) Cryopreservation of proliferating meristem cultures of banana. In: Engelmann F, Takagi H (eds) Cryopreservation of tropical plant germplasm, current research progress and applications. Proc JIRCAS/IPGRI Joint Int Workshop. IPGRI, Rome, pp 238243

Panis B, Schoofs H, Remy S, Sagi L, Swennen R (2000b) Cryopreservation of banana embryogenic cell suspensions: an aid for genetic transformation. In: Engelmann F, Takagi H (eds) Cryopreservation of tropical plant germplasm, current research progress and applications. Proc JIRCAS/IPGRI Joint Int Workshop. IPGRI, Rome, pp 103-109

Reynolds ES (1963) The use of lead citrate at high pH as an electron-opaque stain in electron microscopy. J Cell Biol 17:208-212

Sakai A (2000) Development of cryopreservation techniques. In: Engelmann F, Takagi H (eds) Cryopreservation of tropical plant germplasm, current research progress and applications. Proc JIRCAS/IPGRI Joint Int Workshop. Tsukuba, Japan, pp 1-7

Sakai A, Kobayashi S, Oiyama I (1990) Cryopreservation of nucellar cells of navel orange (Citrus sinensis Obs. var. Brasiliensis tanaka) by vitrification. Plant Cell Rep 9:30-33

Takashi S, Kaneko M, Harada T (1997) Increase in freezing resistance of excised shoot tips of Asparagus officinalis L. by preculture on sugar-rich media. Cryobiology 34:264-275

Tannoury M, Vintejoux C (1997) Etudes cytologiques de bourgeons d'œillet (Dianthus caryophyllus L.) après cryoconservation. Acta Bot Gallica 144:107-118 
Thierry C, Florin B, Pétiard V (1999) Changes in protein metabolism during the acquisition of tolerance to cryopreservation of carrot somatic embryos. Plant Physiol Biochem 37:145-154

Uragami A, Sakai A, Nagai M, Takahashi T (1989) Survival of cultured cells and somatic embryos of Asparagus officinalis L. cryopreserved by vitrification. Plant Cell Rep 8:418-421

Uragami A, Sakai A, Magai M (1990) Cryopreservation of dried axillary buds from plantlets of Asparagus officinalis L. grown in vitro. Plant Cell Rep 9:328-331

Vandenbussche B, Leuridan S, Verdoodt V, Gysemberg M, De Proft M (1999) Changes in sugar content and fatty acid com- position of in vitro sugar beet shoots after cold acclimation: influence on survival after cryopreservation. Plant Growth Regul 28:157-163

Walkey DGA (1978) In vitro methods for virus elimination In: Thorpe TA (ed) Frontiers of plant tissue culture. Calgary University Press, Calgary, Alta. pp 245-254

Wang JH, Ge JG, Liu F, Huang CN (1998) Ultrastructural changes during cryopreservation of rice (Oryza sativa L.) embryogenic suspension cells by vitrification. Cryo-Letters 19:49-54 